\title{
EDUCATING MUSICALLY IN DIFFERENCE: THE CHALLENGES THE ARTS PLACE UPON EDUCATION*
}

\author{
PATRICK SCHMIDT \\ Florida International University, Miami, FL, United States of America
}

\begin{abstract}
AвSTRACT: The aim of this article is to create a link between critical attributes to meaningful educational change and the kind of learning and thinking that is facilitated by artistic endeavors. The goal is not to simply advocate for the Arts, but rather to present a doorway to an educational practice that can be used in educational thought in general. The article starts from David McCarthy's (2000) proposition that "we must think possibility within constraint; that is the condition of our time" (p. 150), arguing that the kinds of thought experiences that individuals'doing art' participate in, can serve as a model for educational thinking, particularly given the complexity, volatility and speed realities of a $21^{\text {st }}$ century education.

KEY WORDS: Arts. Music education. Complex ecology. Education reform. Policy.
\end{abstract}

\section{INTRODUCTION}

In an inventive article on ethics and education David McCarthy (2000) writes, "we must think possibility within constraint; that is the condition of our time" (p. 150). I am inclined to agree on two fronts: Firstly, the volatile nature of educational reform and policy planning requires not only, adaptability, but also a clear sense of how to wisely allocate resources. Secondly, creative solutions are the key to establishing an educational reform that is not reactionary, shortsighted or short-termed, but attempts to create a porous environment where contextual adjustment can still take place.

\footnotetext{
* Artigo recebido em 4/11/2013 e aprovado em 24/1/2014.
} 
It is therefore important to consider in what ways the arts and arts education can be a contributor to this process. If we consider and accept that artistic endeavor is most often represented not by unrestrained freedom - contrary to idyllic visions of art - we might then entertain a more realistic modus operandi for the artistic process where possibility - creativity, innovation, satire - are a response to, and in a sense, arise from constraint scarce resources, uniformity, consumption. Out of such a frame of thought, where possibility and constraint are in a constant, foundational relationship the question arises: What, if anything, can arts education and arts production contribute to the re-thinking of educational aims today?

The aim of this article is to create a link between critical attributes to meaningful educational change and the kind of learning and thinking that is facilitated by artistic endeavors. The goal is not to simply advocate for the Arts, but rather to present a doorway to an educational practice that can be used in educational thought in general. The purpose is not to say that music, my field of expertise, is significant, essential, valuable, and therefore deserves a place in the curriculum; but rather to argue that the kinds of thought experiences that individuals'doing art' participate in, can serve as a model for educational thinking, particularly given the complexity, volatility and speed realities of a $21^{\text {st }}$ century education.

\section{ESTABLISHING A STANDPOINT}

It is not difficult to perceive or accept that unidirectionality, or the presentation of arguments and practices as predetermined, fixed positions, has become common today. At the macro level for instance, the Organization for Economic Co-operation and Development (OECD) is today one of the most impactful organizations in terms of shaping educational standards globally (see OECD, 2004). Indeed, governments, whatever their political leaning, see the OECD's ranking of educational achievement as one of the most anticipated commentaries on social and economic development. It is not surprising, then, that the growth of a structure which places the complex world of education within the economically driven and significantly simpler (at times even simplistic) framework of productivity and efficiency is ideologically aligned with the marketization of education. This notion of education offering "the prospect of constant advancement" (BARNETT; FINNEMORE, 2004, p. 17) is nothing if not a clear example of unidirectionality and how impactful it has become in policy, politics and polity.

Similar pressures extend the gamut from macro governmental policy to micro school-based action, where what Steven Ball (2003) has called 
performativity, or the over emphasis on efficiency, often functions as the key educational indicator for decision-making. It is not surprising then that the inability to hear other arguments - a hallmark of unidirectionality - is an increasing phenomenon in relations among institutions and individuals alike. This is evident in the production of legislation and, consequently, the design and implementation of policy, but is also found in the civic discourse of much of our polity, as well as in the mindset guiding our politics.

What is interesting, and the central stance this article will further develop, is that creative, interactive, highly inventive and multidirectional constructs and practices are indeed regularly developed within the arts, and more specific to my argument, within music. While such complex endeavors are also found in, let's say, innovative computing and technology, the arts present a proximity to educational aims that is less readily available in other areas. Therefore, it is worth exploring in what ways challenging musical/artistic practices can serve as a paradigm and example for educational reform today.

My standpoint is established via three YouTube videos, all demonstrating similarly divergent thinking, while also suggesting some pedagogical potential. Essentially, they represent the fruitful interaction between possibility and constraint. The first video named "How to write a fugue Or an overdose of Danny Pi" reveals a media-rich kind of teaching that is principally guided by a postmodern disposition where multiple voices coexist - literally and metaphorically - in a constant play between consonance and dissonance. The video by Pi cleverly uses the fugue as a tool, a place of convergence, where informal and formal practices can align, where classical form and popular disposition mix, and where humor, critique and sardonic questioning model how a $21^{\text {st }}$ century education is shaped (see http://www. youtube.com/watch?v=tgDcC2LOJhQ). What the video shows brilliantly is how the constraint of tradition is also the porous space from which new possibilities for learning can take form. Consequently, it challenges our expectation of unidirectionality of a certainly belabored tool such as the fugue. It shows us that educational change can be effective without being drastic.

The second video, by Daito Manabe, is linked to the work developed at the Columbia Music Lab and shaped by Douglas Repetto's concept of "doing it wrong". The general precept it instigates is how to develop work from an alternative thinking stance, that is, flipping assumptions into their heads, and establishing new ways of considering familiar phenomena. The video, again, laden with humor (perhaps black humor), asks the question, what happens when music plays us? At its most essential level the video challenges unidirectionality by questioning the assumption that we are always subjects 
in the process of music making. Further, by linking art and technology, by blurring the borders between aesthetics and experimentation as the aim of musical construction, and by simply challenging us to consider the outcomes of a process where people have to re-evaluate what it means to be an 'active' participant, Manabe presents us with artistic, practical and philosophical questions that have commanding educational considerations (see http:// www.youtube.com/watch?v=pLAma-IrJRM). Consider then the implications for curricular changes that could be spurred by such a video, for instance: what shall we consider'active' playing or learning today in the case of general education? Or, is manipulation a constant element in and of the educational process? Or, what is required of a product for it to be called creative?

The last video comes from Brazil and presents one simple but significant example, to my mind, of the collaborative and public education work that Non-Governmental Organizations continue to develop. This aula pública developed by Electrocooperativa from Salvador, shows artistic work as it meets demands for democratic participation, open access and a popular education which addresses political concerns as a direct part of general educational aims (see http://www.youtube.com/watch?v=odmiDYFkQ5Y). As a key educational constraint remains, access the video shows the possibilities in flipping the dynamic of 'students' being brought into the educational setting, by creating educative purpose out of the public sphere of everyday life.

Together, these videos present a rich context on which to think out the role of the arts, and music in particular, as a catalyst for innovative educational thinking. Again, they are presented not as a way to 'advocate' for the importance of the arts - I take that as a foregone assumption - but rather as a way to emphasize the unique opportunities the arts present as a stand point, that is, as one more, complex and adaptable frame from which to reclaim education from the realm of efficiency and performativity (BALL, 2003).

\section{THINKING DIFFERENTLY TO ACT DIFFERENTLY}

Before I further address the potential exemplified by the videos above, it is important to stress that I use the notion of complex ecology (WeAVER-HIGHTOWER, 2008) to stipulate the 'big picture' that this article attempts to construct. As all three videos suggest that this complex ecology is epistemic, psychological as well as pedagogical, thus offering a counterperspective to the unidirectionality detailed above. Network organizations, such as businesses and schools, have used the kind of spherical or ecological thinking I suggest here in the hope of finding new metaphors to frame plans of action. Only recently, however, do we see ecological thinking expressed 
as more than systems or network thinking, where efficient communication and connectivity are really the focus. What I suggest and what the videos exemplify is different as it attempts to acknowledge complexity as a helpful, productive and healthy element in artistic and educational encounters. The said complexity facilitates linkage between the evaluation of internal demand and external opportunity and consequently helps a divergent frame of mind; that is, an acceptance that we can integrate constructively into multiple and at times contradictory discourses (LuCA; PERRONE, 2001).

A critical area to which this thinking can apply is that of policy, given that if policy is to generate wide spectrum buy-in within any field, it must shift from a model of unidirectional mandates to a system of multidirectional contributions. The internal demands of fields and the external possibilities in communities today are linked and made more complex by the speed of communication, new technologies, and the expansion of economies (JONES, 2008; FLORIDA, 2003), as well as the changes in societal mores, expectations, and needs. Therefore, a complex ecological way of thinking could be used in the formation of guidelines to the kind of policy and policy thought that is aided by directives, derived from condensation and focus, but is strongly guided by conceptualization which structures, suggests, and invites complex thinking and language. The implication is that policy would move beyond close-ended objects - for example legislation or standards - acting as an invitation for discourse among a knowledgeable community, instead of as a dictum to an uninformed field. The outcome is significant when we consider what Schneider and Ingram (1997, p. 6) have argued, namely, that "policy designs that enable citizens to participate, learn, and create new or different institutions, and that break down divisive and negative social constructions of social groups lay the foundations for self-correcting policy dynamics and a more genuine democratic society."

Starting from the notion that participation is "evoked to signal the ways in which the collective obligation of society is organized in specific locales and through specific groups of people who can decide what is reasonable for the processes of change" (POPKEWITZ, 2001, p. 45), we can begin to see reform as a process of slight but constant movement, rather than abrupt or seismic ruptures. Local needs drive change and require constant careful rearrangement, which at times provides new products, which in turn require us to think and act differently. This perspective is similar to Geertz's (1973) claim that the results which new visions, ideals, and theories generally contrive to achieve more often than not "grows out of the delicacy of its distinctions, not the sweep of its abstractions" (p. 25). 
When we look at Daniel Pi's video, it is clear that the abstraction of approximating informality and formality is not'sweeping', but is nevertheless, radical. That is, it jolts us, offering radical humor and radical delivery of content, while maintaining a certain familiarity that helps us, pedagogically, to understand what is new and what is recycled. The teaching that the video produces then is radical yet delicate, which is exactly the kind of paradigmatic understanding that is specific to art and music and can have a significant effect on the kind of conceptions of learning we should attend to in our $21^{\text {st }}$ century realities. Pi's video, by not only repositioning the terms of musical treatment of a very traditional form - the fugue - aids in its learning while disturbing it. It makes it cool while snubbing it at the same time. The same is done to teaching then, presenting it as multi-track, needing erudition but requiring that it be up-to-date, of this world and ready to open itself to critique. What the Pi video shows us is that the larger challenge for the field of education is not to create new thinking, but to generate thought that can adapt to constant change. This is also significant because it allows a'lesson' - a teaching segment - to travel, to become mobile. I believe that the promise of mobility departs from authenticity understood as something done locally, done in the moment and within a particular context, while sustaining great awareness of the global. There is no doubt that this is difficult and challenging, but it might also become quite powerful, as it may communicate well, traveling and thus allowing the kind of linkage that forms a complex ecology of learning that we have talked about here.

The videos which frame this article demonstrate how ecology is predicated on a multiplicity of interrelations and interdependencies that are embedded in all situations. The aula pública shows this, for example, by emphasizing the constancy of adaptation and mutation, which are necessary as concepts, notions, articulations, deliberations, and practices continue to change. In an investigation of arts-based Non-Governmental Organizations in Brazil (see SCHMIDT, 2013) I use the notion of place-centered learning to argue for the importance of NGOs and the kind of artistic education they produce. There, I use Gruenewald (2008) to highlight the meaning behind the spaces or ecologies that surround us, given that "fundamentally significant knowledge is knowledge of the unique places that our lives inhabit; failure to know these places is to remain in a disturbing sort of ignorance" (p. 143). The aula pública video is a concrete example of how to respond to Gruenewalds's challenge, as it takes education to the streets, tapping into and learning from the multiple views of the constituencies that establish the content and the context of class. 
What we start noticing here is a space where teacher and student agency can grow together. This growth is facilitated by a sharing culture but also by changing the idiom of teaching, focusing less on delivery and more on learning. What I mean here is that, the traditional movement toward a sequential teaching and planning, where the aim is to converge information that will then be digested by students, is replaced by a model that privileges divergence, that is, the complex ecology we have talked about, where students balance pre-organized information and pedagogical challenges to self-directed learning.

\section{Creative parameters as the neW Informal}

Given the paucity of space available here, I would like to suggest that the reader also follow a "prezi presentation" available online at (http://prezi. com/u_bkqft-m3dq/edit/\#2_740596). The presentation adheres somewhat to the ideas in this article, but also provides divergences, that is, it provides other examples, ideas, and structures that create a similar but also different ecology that compliments or extends that of this article. To define this ecological frame I follow Weaver-Hightower (2008) who sees education as a "complex, often contradictory process that defies the commonly held image of singular purpose and open, effective planning" (p. 153). I would argue then that this complex ecology is the defining element of a new "informality" in arts and music education.

The distinction between that which is formal as classroom and teacher centered, and that which is informal as student-led and classroom decentered is too narrow to remain pertinent (for a detailed critique see GeORGII-Hemming; WestaAl, 2010). What I suggest and what the videos above exemplify, is that informality is today defined by an engagement with a complex ecology, encompassing the formal within itself. Further, I would argue that, exactly as the videos suggest, art-based learning when properly undertaken, embodies this complex ecology and consequently can serve as a model for general educational enterprises. Specifically, I would argue that informality takes as inept and pernicious learning that aims at "value-neutral decision making" and those which ignore "issues of power." Such models are not only ineffective, but are also misleading. Furthermore, I would argue that this informality can be characterized by the following precepts: 1 ) Music teaching and learning should be compatible with culturally viable but vibrant models; 2) Collaborative learning structures should be used, but must aim at expanding and disrupting current practices; 3 ) Community engagements 
must consider how they are linked to lifelong interaction with music; and 4) Informality is centered around educational agency.

While I understand that forces larger than those teachers can contend with might be at play here, it is also the case that practice based on creative and critical conceptualization - central to the informality as expressed here can have an impact on attitudes, perception and could eventually impact school and community cultures. What videos such as those of Pi's or Manabe demonstrate is the beginning of a query that asks if and when the arts give too little attention to 'out of the ordinary ideas.' The prezi link shows several examples where teaching and learning in music are based on pedagogical reinterpretation, educational transformation, or structural repositioning. Videos such as those describing a new ipad ensemble, or the Canadian multitrack singer, or that highlighting Eric Whitacre's virtual choir demonstrate how this is being done today. This kind of music education is, as Väkevä (2012) contends, a thoroughly mediated art form, and as such, any attempt to focus on its alleged authentic messages only veils its cultural transformative role and consequently diminishes the educational capacity it carries. Central to informality, as a parameter for teaching and learning, is the fact that it draws from an "infinite archive" of new media while it also impacts, and caters to new cultural expressions and aesthetic sensibilities.

Of course, there are many critiques of such conceptualization. Hatfield (1999) for example, critiquing what he sees as the misguided movement of arts education toward exposure rather than education - a misinterpretation of what I suggest above - writes that "it is questionable whether students grasp many of the references of less explicit messages of popular culture," and concludes that "just as exposure is not education, information is not knowledge and access is not comprehension" (p. 9). Although his logic is certainly convincing, he misses the reality that "substantive" arts learning in this framework rests on the assumption of particular knowledge formations and encounters that are based on time commitments - that is, long-term, drillbased engagements - that have been dissolved by contemporary modes of thinking, new technologies and societal restructuring. An education, I would argue, is not the eventual result of deep-seated efforts, nor the pay-off of arduously delayed gratification. Rather, it is the development of a framing capacity, where I am helped and challenged to understand and trouble my contexts.

Informality as I offer it here, as well as the artistic production that is widely organized around and distributed via YouTube, represents new parameters for the construction of knowledge. They model how knowledge 
can be built from the underlying assumption of a milieu where interaction and interactivity are taken for granted. Therefore, knowledge is developed with the acknowledgment that it will mutate the moment it is finished and shared (a reality that is common in both electronica music and hip-hop). New formats, then, may imply immediate gratification and superficiality, but this is perhaps because we do not yet know how to read them.

Allan Kozinn (2008), of the New York Times, reported on the formation of the "new" musician: one who is at heart an entrepreneur and for whom the merging and crossing of musical traditions has transformed borders into borderlands. These borderlands, these spaces which are not clearly defined and where multiple identities are feasible, are spaces where we can address what Lindblom (1990) has called "agents of impairment", such as dominant ideology, lack of information, bureaucratic restrictions, among others. Knowing how to talk and listen are critical skills for as we know, "in a political world [such as that of schooling] what any party believes to be possible at all depends of their assumptions about other parties" (FoRESTER, 2006, p. 126). Furthermore, the capacity to frame one's issues, to adapt and to envision the complex environment upon which new action can take place is essential.

In practical terms, informality, moves toward the acknowledgment that teachers will likely face situations of conflict, have to address and overcome unequal power relations, as well as simply address organizational messiness. Majone (1989) refers to this as a fight against 'decisionism' that is particularly unhelpful in education environs given the complexity of the tasks, the multiple constituencies and standpoints, and the high level of professional engagement of its constituents (administrators, teachers, parents).

Simple shifts from positioning that closes discussion such as "this is what I think should happen... any thoughts?" to framings such as "does this address or misses your needs?" show another way to represent a disposition toward critical interaction. Forester (2006) argues that "inter-viewing", that is, seeing between visions - can help us reformulate interests (how we might act), reshape our relationships (who "we" are) and reposition our interests (what we really care about). This 'inter-viewing' is another way to define the kind of'teaching-learning'relationship present in all three videos used in this article. Thus, Pi's inter-view approximates two different musical worlds, and the Mandabe inter-view approximates subject and object in musical doing, while the inter-view offered by the aula publica approximates classroom context as central to classroom content. 


\section{RE-SETTING POLICY AS A REACHABLE SPACE FOR TEACHERS}

While the arguments above deal with the micro-level concerns of the classroom, they might also help us to think about the macro-level of policy. Moreover, they show us how these two realms, often considered apart, can and perhaps should be approximated. This is important because part of the mystique of policy, part of the reason it has remained detached from teachers, is that it has been presented as a self-standing structure, established via "formulation" and "implementation" patterns detached from contextual insight and constituency contact. Indeed, traditional stances on policy at times can be anathema to an encompassing civic culture, with systems and protocols which are "responsive" only to very few (Lowl, 1979). The lack of trust this engenders can easily "recast the role of policy in society from the 'pursuit of the public welfare' to the weighing and balancing of competing interests" thereby generating disillusion and lack of participation (SCHNEIDER; INGRAM, 1997, p. 20).

Christiansen (2008) shows us an example of the problem, when pointing to Portland, Oregon. There, the city superintended instituted policies that were supposed to address "equity and social justice" but that were operationalized in solely formal ways, dismissing the complex ecology required to bring such a difficult subject to life. The result was that "equity and social justice" became obligatory "anchoring tasks" forced on teachers with the objective of streamlining instruction. The informality of multiple voices or of open learning based on challenges to self-generated critique, were absent. And the establishment of goals such as "equitable distribution of educational opportunities" was flattened into standardized instruction. The process can be summed up as follows: The projected ideal was equity and social justice, but the strategy followed a Fordist efficiency model. The result was the decentralization of teachers as the locus of pedagogical and curricular decisions - in other words, the erasure of teachers as policymakers.

Of course to counteract this kind of misguided educational policy, our understandings of policy must change. And we may start by considering that "policy is pursued by a vantage point and constitutes a subjective endeavor that is contingent on interpretation (GALE, 2001, p. 134). Or by understanding that policy environments are "multidimensional and interactive networks made of structures and actors" (LIASIDOU, 2012, p. 74), which therefore require our participation. Because of the multiplicity of contexts in education today, researchers have started to focus on policy environments and how teachers react and adapt to them (KNAPP, 2004). Grossman and Thompson (2004), 
for instance, investigated the impact of policy environments, at the district level, on young teachers. They argued that "relatively little attention has been focused on the contexts in which beginning teachers work and how these contexts shape their beliefs, concerns, practice, and opportunities for learning" (p. 282). Indeed, "if policy itself is a curriculum that must be learned, opportunities for learning new policy [language] must be a part of the process of policy enactment" (p. 283).

This would mean that we would see policy as complex and contested, just as any educational effort. Such views would place us, arts and music educators, as bona fide actors in the policy realm who can make ourselves capable of what Grace (1991) calls "policy scholarship", that is, generating "a tool box of diverse concepts and theories" and consequently be able to decenter a now old-fashioned notion of 'policy science' that is "seductive in its distance, concreteness and apparent value free stance" (p. 7). While reliable information and decision-making should be essentially linked, valuing data is not akin to the misguided establishment of efficiency and what Steven Ball (2003) has called 'performativity' as definitional to policy practice. Educational policy cannot be the realm that displaces concerns with process, constituencies, contextual-needs, and contestation. On the contrary, policy investigation must be "that which takes account of people's perceptions and experiences" (OzGA, 1990, p. 359).

It should be clear now that the kind of framing capacity provided by the arts is central to the argument of this article. Not only is this framing capacity significant as a way of thinking and being productive, but it also helps to construct participative teaching and learning, and to dislodge the inputoutput vision of education articulated above. I would highlight that this is not simply a philosophical ideal but a pragmatic element. Indeed, the section of the prezi presentation under the title civic engagement, exemplifies how my own students, for example, practice writing their own 'policy briefs' during their freshman experiences, learning to name issues important to them as educators, express pathways to address them, and generate the rich context where curriculum will be developed. Of course these practical actions are supported conceptually (see the chart delineating the notion of scholarship of engagement as one example) and philosophically (see the video where a student presents her "music education manifesto"). Together they exemplify a concrete representation of the complex ecology I argued for in this article, showing that it is indeed feasible for us to actively foster these ideas with current and future educators. 


\section{Challenges OF IMPLeMENTATION}

As I have written elsewhere (SCHMIDT, 2012a) the geopolitical challenges we face in education are also present in art. Politically and pedagogically, those of us in the field are regularly reminded of: 1) the changing job status of artists; 2 ) the variability of markets and how music/ art is produced and distributed; 3 ) the increasing emphasis on efficiency in public expenditure; and 4) the new consumption and participation patterns in art and their impact on cultural policies.

A significant challenge in the connection between arts education and general education is that both must pay attention to what McWilliam (2009) calls the need for "extending our meta-categories of pedagogy" which would be fostered by teachers "who prioritize the building of creative capacity in students, with 'creative' being understood as a propensity for epistemological agility" (p. 282). The latter is established by a long line of scholarly enterprises ranging from the capacity to approximate habitually incompatible models (KoESTLER, 1964) and the notion of mental models (PERKINS, 1981) all the way to recent notions of 'multi-competent graduates' (YORKE, 2006). They culminate with the realization that teachers, like other professionals, will be"performing work that is less focused on routine problem solving and more focused on new social relationships and novel challenges" (McWiLliam, 2009, p. 284).

What all three videos above help us see is that teaching and learning are shaped today by new kinds of interactions and unusual pedagogical 'channels'. The picture outlined by creative framing capacity might indeed be of teachers who work/learn more like gamers (BECK; WADE, 2006) who are "less anxious in the absence of top-down rules" and "learn to use a meta-map or to operate without one, rather than take instructions from 'outside' the subculture" (p. 2). If videos such as those in the article can be said to foster a model or an exemplification of how to think educational practices from an arts or artistic standpoint, they may also have something to say about an engagement with the notion of a public sphere of learning (PSL) where agency and creativity abound. In practical terms what begins to be established here is the understanding that while teachers must be fluent in their subject knowledge, it is just as important to be willing to model adaptability and establish creative learning engagements (CLE) where they show "how to be usefully ignorant and assist students who fear not having all the answers all the time" (McWILLIAM, 2009, p. 287).

One of the key challenges is that communities, such as schools, are often see and constructed to serve as a "moral unity that stands above the population and its interactions, like a sovereign power" (HARDT; NEGRI, 2004, p. 
204). Robert Putnam has helped us to see the positive effects of strong ties and the cultural capital that is formed by close knit communities, but Hardt and Negri point out the deficiencies that are not unusual in educational communities which are led or choose to operate in insular ways. The reproductive nature of communities of practice is widely known in music education. We need only think of ensemble-based practices maintained without challenge for generations, or of elementary music education formats where early $20^{\text {th }}$ century models of methodological thinking are still pervasive, at least in the US context. The challenge presented by the videos is: How can we institutionalize the adaptability and variance we see in them? The questions at the doorstep of every educator are: Can we systematize the creative/artistic disposition at the heart of these videos? Can we disseminate the notion of pedagogical development as beyond perfecting sequential delivery of information? Can we offer spaces for experimentation, where one experiences familiar patterns - and all the videos show recognizable learning/ teaching patterns - but also innovation and surprise, used as pedagogical tools to raise interest, participation, reflection, criticism? Can we learn to do so without normalizing them, without flattening them into didactic versions of the "real thing"?

One step forward might be taken by seeing that the nature of the propositions discussed by the videos here is that of a commons. Hardt and Negri (2004) define the educational experience of a commons as that where the individual never "dissolves in the unity of the community" but remains a singular entity that is always in relation to "collaborative social processes" (p. 205). Commons then are models for a public sphere of learning as they offer an orientation toward constructive tension or controversy (TJOSVOLD, 1998), where creativity learning becomes the capacity to frame and interact differently. Again the challenge is how this gets learned as a process, and an institutional way of doing teaching and learning, where artistic spontaneity and risk-taking are valued. But then again, that is exactly the mode of thinking which guides artistic production and interaction, and therefore, the key element that arts education can provide to education in general.

Another step forward might be to emphasize a renewed relationship between autonomy and accountability where they are not "understood to be in contra-position", arguing that "co-dependence is in fact essential for both to be realized" (p. 221). Similar to the notion embedded in the artistic work that the 'commons' idea facilitates, the aim of an arts based education ought to be to emphasize that autonomy requires agency and latitude, while 
accountability, if it is to be responsible and personal, requires a modicum of autonomy. Consequently,

the ecology formed by this codependence requires actions on two fronts from individuals: 1 ) promoting flexible models of accountability so that autonomy can play its part in developing innovation and asserting diversity, and 2) fostering autonomy that can critically construct analyses of accountability models addressing how, to whose benefit, and toward what ends the models operate. (SCHMIDT, 2012b, p. 222)

In the end, what arts education can contribute and what the videos exemplify form a conception of educational and professional life and processes that "involve not simply the utilitarian business of acquiring technical skills but rather the shaping of humane practitioners, capable, for example, of independent and informed ethical judgment"(BECK, 1999, p. 226).

Taken as a directive for the formation of educators the abovementioned conceptual model and the example in the video show a diversification of roles played by educators, who, "regardless of political realities and policy contingence would act as: 1) Leaders and content providers; 2) Reflective constructors of curriculum; 3) Innovative collaborators; 4) Community builders; 5) Continuous learners; and 6) Political communicators" (SchmidT; RobBins, 2011, p. 98). This multiplicity is both a response to the adaptability needed to survive in complex environs, as well as an expression of a critical leadership, and both are necessary to re-think the relationship between teachers and learning and teachers and their schools.

\section{CONCLUSIONS}

In the US, the current efforts of the Common Core State Standards demonstrate an attempt to return to manageable complexity, establishing learning where literary and artistic parameters are again valued. Indeed, elements of artistic design embodied in the videos I offered here, easily link to educational aims fostered by some aspects of the Common Core Standards, such as attention to "rich texts" which provide fodder for interpretation and re-creation. This renewed progressive vision is not without resistance, but seems a clear reaction to the question: Where has optimization led us?

As Sunstein (2008) has argued, education based on dispensation efficiently acquiring, retaining, and distributing information - leads knowledge to go unconsummated, to remain static and inconsequential. I have argued here that the creative and participative practices exemplified principally by three videos seem to teach us a few lessons on the possibilities 
of the arts for education in general. Further, they seem to suggest a few principles that might guide us when attempting to engage in teaching and learning that are creative and participative. I propose that we consider them as a series of reminders:

- Don't reify limiting "stories";

- Don't reinforce isolation;

- Don't confuse efficiency with simplistic thinking;

- Don't dismiss linguistic impact upon action;

- Don't substitute framing with naming.

In my opinion, the above illustrate "how musical and cultural production can provide forms of leadership that are participative, sharebased, and focused on social challenges, by setting parameters that delimit our work without closing conversation or initiative" (SCHMIDT, 2012b, p. 224).

Lawrence Lessig argued in his 2008 book, Remix, that the central importance of today's diversified places of learning is not simply a more rapid or effective, perhaps even democratic, distribution of information. Rather, it is the manner in which they generate a place for enacting one's own intellectual development through creative acts - where we actively construct text, image, and sound, as well as dialogue, interaction, consensus, and disruption. Music, a practice increasingly mediated by technology, offers, in accordance with Lessig's framework, an almost incessant "mixing" of constructive possibilities. Of course we must also acknowledge that music and artistic practices can also facilitate technocratic education (KUSHNER, 1999), the fetishization of the tool (Pfaffenberger, 1998), and anomie (Arnold; Levitin, 2010). Therefore, as a volatile educative space, musical and arts education must be interwoven with other concerns and other more encompassing constructs if it is to build robust, meaningful, and complex learning outcomes.

The notions and conceptions I offered here present complexity not as an anathema to learning, but as the essential quality for reflexive action and thought - a quality best established when local knowledges are claimed in conjunction with global insights. This ideal can be seen in music and artistic practices today as a technology-driven revolution is changing consumption into creation - what Shirky (2010) called the amateurization of art and music. While some see in this a dilution of 'quality education' what I, and many others, suggest is that emerging from amateur engagement is a credible paradigm in which reflective practices no longer single out perfection and acuity, but foreground "citation, interference, and secondary processes" (p. 85), each inviting us to produce and participate. These are lessons that arts, music 
educators and generalists are learning together. Their time is still in formation, but their promise is plentiful and worth our attention.

\section{EDUCAÇÃO MUSICAL EM DIFERENÇA: OS DESAFIOS DAS ARTES PARA A EDUCAÇÃO}

Resumo: Este artigo tem como objetivo criar ligações entre atributos críticos para a mudança educacional significativa e o tipo de aprendizagem e pensamento que é facilitado por atividades artísticas. Sua meta não é simplesmente advogar pelas Artes, mas sim apresentar um olhar particular sobre uma prática educativa que pode ser usada no pensamento educacional em geral. O artigo parte da proposição de David McCarthy (2000) de que "devemos pensar a possibilidade dentro da restrição; essa é a condição do nosso tempo" (p. 150), argumentando que o tipo de experiências de pensamento em que as pessoas "fazendo arte" participam, podem servir como modelos de pensamento educacional, dadas principalmente a complexidade, volatilidade e a velocidade das realidades educacionais do século 21 .

Palavras-chave: Artes. Educação musical. Ecologia complexa. Reforma da educação. Política.

\section{EDUCACIÓN MUSICAL EN LA DIFERENCIA: LOS DESAFÍOS DE LAS ARTES PARA LA EDUCACIÓN}

RESUMEN: Ese artículo tiene como objetivo crear ligaciones entre atributos críticos para el cambio educacional significativo y el tipo de aprendizaje y pensamiento que es facilitado por actividades artísticas. Su meta no es simplemente abogar por las Artes, sino presentar un portal para una práctica educativa que puede ser usada en el pensamiento educacional en general. El artículo parte de la proposición de David McCarthy (2000) de que "debemos pensar la posibilidad dentro de la restricción; esa es la condición de nuestro tiempo"(p. 150), argumentando que el tipo de experiencias de pensamiento en que las personas "haciendo arte" participan, puede servir como modelos de pensamiento educacional, dadas principalmente la complexidad, la volatilidad y la velocidad de las realidades educacionales del siglo 21.

Palavras claves: Artes. Educación musical. Ecología complexa. Reforma de la educación. Política.

\section{REFERENCES}

ARNOLD, B.; LEVITIN, M. Media and Culture, n. 13, v. 2, 2010.

BALL, S. J. The teacher's soul and the terrors of performativity. Journal of Educational Policy, n. 18, v. 2, p. 215-228, 2003. 
BARNETT, M.; FINNEMORE, M. Rules for the world: International Organisations in Global Politics. Ithaca: Cornell University Press, 2004.

$\mathrm{BECK}$, J.; WADE, M. The kids are alright: how the gamer generation is changing the workplace. Boston: Harvard Business School Press, 2006.

BECK, J. Makeover or takeover? The strange death of educational autonomy in neoliberal England. British Journal of Sociology of Education, n. 20, p. 223-238, 1999.

CHRISTIANSEN, L. The power of words: top-down mandates masquerade as social justice reforms. Rethinking Schools, n. 22, v. 3, p. 18-21, 2008.

FORESTER, J. Policy analysis as critical listening. In: MORAN, M.; REIN, M.; GOODIN, R. (Eds.). The Oxford Handbook of Public Policy. New York: Oxford University Press, 2006. p. 124-151.

FLORIDA, R. The rise of the creative class. New York: Basic Books, 2003.

GALE, T. Critical policy sociology: historiography, archeology, and genealogy as methods of policy analysis. Journal of Education Policy, n. 16, v. 5, p. 379-393, 2001.

GEERTZ, C. The Interpretation of Cultures. New York: Basic Books, 1973.

GEORGII-HEMMING, E.;WESTVALL, M. Music education - a personal matter? Examining the current discourses of music education in Sweden. British Journal of Music Education, n. 27 , v. 1, p. 21-33, 2010.

GRACE, G. School leadership: beyond educational management: an essay in policy scholarship. London: Falmer Press, 1995.

GROSSMAN, P.;THOMPSON, C. District policy and beginning teachers: a lens on teacher learning. Education Evaluation and Policy Analysis, n. 26, p. 281-301, 2004.

GRUENEWALD, D.; SMITH, G. Place based education in the global age. Mahwah, NJ: Lawrence Erlbaum, 2008.

HARDT, M.; NEGRI, A. Multitude: war and democracy in the age of empire. New York: Penguin Press, 2004.

HATFIELD, T. The unevenness of arts education policies. Arts Education Policy Review, v. 101 , n. 2, p. 2-7, 1999.

JONES, P. Policy studies as a component of music teacher education: Building the profession's capacity for strategic action. In: LEUNG, R. L. C.; YIP, Rita L. C.; IMADA, T. (Eds.). Music education policy and implementation: international perspectives. Aomori, Japan: University of Hirosaki Press, 2008. p. 23-34.

KNAPP, M. S. Professional development as a policy pathway. Review of Research in Education, n. 27, p. 109-158, 2004.

KOESTLER, A. The act of creation. New York: Macmillan, 1964.

KOZINN, A. A man of many talents, eager to use them all. New York Times, October 3, 2008. 
KUSHNER, S. Fringe benefits: Music education out of the national curriculum. Music Education Research, n. 1, p. 209-218, 1999.

LESSIG, L. Remix: making art commerce thrive in the hybrid economy. New York: Penguin Press, 2008.

LIASIDOU, A. Inclusive education, politics and policymaking. London: Continuum, 2012.

LINDBLOM, C. Inquiry and change: the troubled attempt to understand and shape society. New Haven: Yale University Press, 1990.

LOWI, T. American business, public policy, case-studies and political theory. World Politics, n. 16, p. 677-715, 1979.

LUCA, F.; PERRONE, A. Agent-based methods in economics and finance: simulations in swarm. Boston: Kluwer Academic, 2001.

MAJONE, G.; Wildavsky, A. Implementation as evolution. In:PRESSMAN, L.; WILDAVSKY, A. Implementation: how great expectations in Washington are dashed in Oakland. Berkeley, CA: University of California Press, 1979.

MCCARTHY, D. Harming and allowing harm. Ethics, n. 110, v. 4, p. 149-79, 2000.

MCWILLIAM, E. Teaching for creativity: from sage to guide to meddler. Asia Pacific Journal of Education, v. 29, n. 3, p. 281-293, 2009.

ORGANISATION FOR ECONOMIC CO-OPERATION AND DEVELOPMENT (OECD). Learning for tomorrow's world: first results from PISA 2003. Paris: OECD, 2004.

OZGA, J. Policy research and policy theory: a comment on Fitz and Halpin. Journal of Education Policy, n. 5, v. 4, p. 359-362, 1990.

PERKINS, D. The mind's best work. Cambridge, MA: Harvard University Press, 1981.

PFAFFENBERGER, B. Fetishized objects and humanized nature: towards an anthropology of technology. New Series, n. 23, p. 236-252, 1998.

POPKEWITZ, S. Pacts/partnerships and governing the parent and child. Current Issues in Teacher Education, n. 3, v. 2, p. 122-141, 2001.

REPETTO, Douglas. Doing it wrong! Frontiers of engineering: reports on leading-edge engineering from the 2010 symposium. Disponível em: <http://www.nap.edu/catalog/13043.html>.

SCHNEIDER, A.; INGRAM, H. Policy design for democracy. Lawrence, KA: University Press of Kansas, 1997.

SCHMIDT, P. NGOs as a framework for an education in and through music: Is the third sector viable? International Journal of Music Education, published online 24 June, 2013. Disponível em: <http://ijm.sagepub.com/content/ early/2013/06/24/0255761413488707>.

SCHMIDT, P. Music, policy and place-centered education: finding space for adaptability. In: SCHMIDT, P.; BENEDICT, C. (Eds.). National Society for the Study of Education, v. 111, p. 51-73. New York: Teachers College Press, 2012a. 
SCHMIDT, P. Critical Leadership and Music Educational Practice. Theory Into Practice, n. 51 , v. 2, p. 221-228, 2012 b.

SCHMIDT, P.; ROBBINS, J. Looking Backwards to Reach Forward: a strategic architecture for professional development in music education. Arts Education Policy Review, n. 112, v. 2, p. 95-103, 2011.

SHIRKY, C. Cognitive surplus: creativity and generosity in a connected age. New York: Penguin Press, 2010.

SUNSTEIN, C. Infotopia: how many minds produce knowledge. Oxford: Oxford University Press, 2008.

TJOSVOLD, D. Cooperative and competitive goal approach to conflict: Accomplishments and challenges. Applied Psychology: An International Review, n. 47, p. 285-342, 1998.

VÄKEVÄ, L. Digital artistry and mediation: (re)mixing music education. In: SCHMIDT, P; BENEDICT, Cathy (Eds.). The place of music in the 21st century: a global view. New York: Teachers College Press, 2012.

WEAVER-HIGHTOWER, M. An ecology metaphor for educational policy analysis: a call to complexity. Educational Researcher, v. 37, n. 3, p. 153-67, 2008.

YORKE, M. Employability in higher education: what it is - what it is not. York, UK: Higher Education Academy, 2006.

PATRICK SCHMIDT é professor titular de Educação em Música e diretor adjunto da Escola de Música da Florida International University, Miami, USA. Oferece cursos em filosofia, pesquisa, currículo e política, assim como cursos em métodos corais e secundários, hip hop e educação musical em escolas urbanas. Suas obras mais recentes foram publicadas no International Journal of Music Education, Arts Education Policy Review, Journal of Curriculum Theorizing, Theory into Practice, Philosophy of Music Education Review, Action, Theory and Criticism, Journal of Music Education da Finlândia e a Revista do ABEM no Brasil. É coeditor do NSSE Book de 2012 da Teachers College Press e está atualmente coeditando o Oxford Handbook for Social Justice and Music Education.

E-mail:pschmi@fiu.edu 